Pontifícia Universidade C $_{\text {atólica }}$

Bruno Lopes Vieira

Extending Propositional Dynamic Logic for Petri Nets

Thesis presented to the Programa de Pós Graduação em Informática of the Departamento de Informática, PUC-Rio as partial fulfillment of the requirements for the degree of Doutor em Informática

Advisor : Prof. Edward Hermann Haeusler Co-Advisor: Prof. Gilles Dowek 

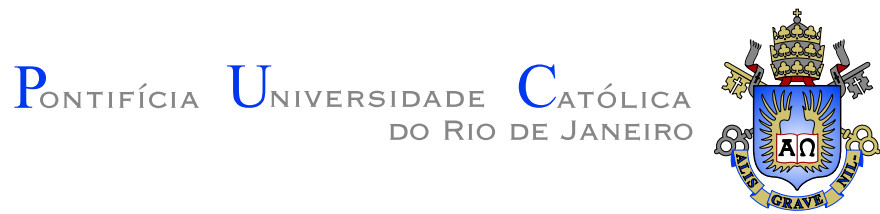

Bruno Lopes Vieira

\section{Extending Propositional Dynamic Logic for Petri Nets}

Thesis presented to the Programa de Pós Graduação em Informática of the Departamento de Informática, PUC-Rio as partial fulfillment of the requirements for the degree of Doutor em Informática. Approved by the following commission:

Prof. Edward Hermann Haeusler

Advisor

Departamento de Informática - PUC-Rio

Prof. Gilles Dowek

Co-Advisor

INRIA

Prof. Cláudia Nalon

UnB

Prof. Luiz Carlos Pinheiro Dias Pereira

Departamento de Filosofia - PUC-Rio

Prof. Jorge Petrucio Viana

UFF

Prof. Geiza Maria Hamazaki da Silva

UNIRIO

Prof. José Eugênio Leal

Coordinator of the Centro Técnico Científico - PUC-Rio

Rio de Janeiro, March 28th, 2014 
All rights reserved.

\section{Bruno Lopes Vieira}

Bruno Lopes graduated from the Universidade Federal de Alagoas (UFAL - Alagoas, Brazil) in Computer Science. He finished his master's thesis at the Universidade Federal de Alagoas (Alagoas, Brazil) in Computational Knowledge Modelling. He then obtained a D.Sc. at the Pontifícia Universidade Católica do Rio de Janeiro (PUC-Rio - Rio de Janeiro, Brazil) in Informatics (Theory of Computation).

Bibliographic data

Lopes, Bruno

Extending Propositional Dynamic Logic for Petri Nets / Bruno Lopes Vieira ; advisor: Edward Hermann Haeusler; coadvisor: Gilles Dowek. — 2014.

$101 \mathrm{f}$ : : il. ; $30 \mathrm{~cm}$

Tese (Doutorado em Informática)-Pontifícia Universidade Católica do Rio de Janeiro, Rio de Janeiro, 2014.

Inclui bibliografia

1. Informática - Teses. 2. Lógica. 3. Lógica Modal. 4. Lógica Dinâmica. 5. Redes de Petri. 6. Redes de Petri Estocátiscas. I. Haeusler, Edward Hermann. II. Dowek, Gilles. III. Pontifícia Universidade Católica do Rio de Janeiro. Departamento de Informática. IV. Título. 


\section{Acknowledgments}

To my parents and my sister for all of their comprehension and kindness during this process. To my aunt Elenilda and my uncle Givaldo.

To Prof. Edward Hermann Haeusler, advisor and friend. I will always be thankful for all I have been learning with him and for all of his friendship. To Prof. Gilles Dowek who also advised me. Thank you for all of your attention.

To Prof. Mario Benevides with whom I could work since the begin of this work. It is a pleasure to collaborate with you.

To Prof. Luiz Carlos Pereira, wherewith I have the pleasure to be always learning. To Prof. Geiza Hamazaki, a great friend who helped me since I arrived in Rio. It is a pleasure to work with you. To Prof. Valeria de Paiva, that always encouraged me.

To Prof. Cláudia Nalon. It was a great pleasure to work with you. To Prof. Petrucio Viana. Thank you for sharing your experience.

To the colleagues at TecMF that were greater partners in this journey, specially Cecilia Englander, Jefferson Santos and Fernanda Lobo. It was really a pleasure to work with you.

To all of the colleagues at Deducteam (INRIA), specially to Alejandro Díaz-Cairo, Hugo Macedo and Kailiang Ji.

To Prof. Alejandro Frery and Prof. Eliana Almeida, who encouraged me and for all the friendship.

To Prof. Jean-Baptiste Joinet, who kindly received me in Paris.

To the friends that were part of this journey, Alexandre Rademaker, Christiano Braga, Isabel Cafezeiro and Vaston Costa. I really appreciate to be among you.

To the friends Elaine Pimentel and Carlos Olarte, for all the conversations and all the great time we could spend.

To the administrative staff of PUC-Rio, specially to Alex Alves, Fátima Holanda, Regina Zanon, Ruth Maria de Barros, Selma Muñoz, Teresa Canuto and Vagner Pires. Thank you for the help in all these years.

To Henrique Rocha, for all the comprehension and partnership in all these years.

To the CNPq and CAPES for supporting my research.

To everybody who, directly or not, contributed in this journey, thank you. 


\section{Abstract}

Lopes, Bruno; Haeusler, Edward Hermann (advisor); Dowek, Gilles (coadvisor). Extending Propositional Dynamic Logic for Petri Nets. Rio de Janeiro, 2014. 101p. D.Sc. Thesis - Departamento de Informática, Pontifícia Universidade Católica do Rio de Janeiro.

Propositional Dynamic Logic (PDL) is a multi-modal logic used for specifying and reasoning on sequential programs. Petri Net is a widely used formalism to specify and to analyze concurrent programs with a very intuitive graphical representation. In this work, we propose some extensions of Propositional Dynamic Logic for reasoning about Petri Nets. We define a compositional encoding of Petri Nets from basic nets as terms. Second, we use these terms as PDL programs and provide a compositional semantics to PDL Formulas. Then we present an axiomatization and prove completeness regarding our semantics. Three versions of Dynamic Logics to reasoning with Petri Nets are presented: one of them for ordinary Marked Petri Nets and two for Marked Stochastic Petri Nets yielding to the possibility of model more complex scenarios. Some deductive systems are presented.

The main advantage of our approach is that we can reason about [Stochastic] Petri Nets using our Dynamic Logic and we do not need to translate it into other formalisms. Moreover our approach is compositional allowing for construction of complex nets using basic ones.

\section{Keywords}

Logic; Modal Logic; Dynamic Logic; Petri Net; Stochastic Petri Nets; 


\section{Resumo}

Lopes, Bruno; Haeusler, Edward Hermann; Dowek, Gilles. Extensões de Lógica Proposicional Dinâmica para Redes de Petri. Rio de Janeiro, 2014. 101p. Tese de Doutorado — Departamento de Informática, Pontifícia Universidade Católica do Rio de Janeiro.

Lógica Proposicional Dinâmica (PDL) é um sistema lógico multi-modal utilizada para especificar e verificar propriedades em programas sequenciais. Redes de Petri são um formalismo largamente utilizado na especificação de sistemas concorrentes e possuem uma interpretação gráfica bastante intuitiva. Neste trabalho apresentam-se extensões da Lógica Proposicional Dinâmica onde os programas são substituídos por Redes de Petri. Define-se uma codificação composicional para as Redes de Petri através de redes básicas, apresentando uma semântica composicional. Uma axiomatização é definida para a qual o sistema é provado ser correto, e completo em relação à semântica proposta. Três Lógicas Dinâmicas são apresentadas: uma para efetuar inferências sobre Redes de Petri Marcadas ordinárias e duas para inferências sobre Redes de Petri Estocásticas marcadas, possibilitando a modelagem de cenários mais complexos. Alguns sistemas dedutivos para essas lógicas são apresentados.

A principal vantagem desta abordagem concerne em possibilitar efetuar inferências sobre Redes de Petri [Estocásticas] marcadas sem a necessidade de traduzí-las a outros formalismos.

\section{Palavras-chave}

Lógica; Lógica Modal; Lógica Dinâmica; Redes de Petri; Redes de Petri Estocátiscas; 


\section{Contents}

1 Introduction $\quad 10$

2 Definitions $\quad 14$

2.1 Basic logical definitions 14

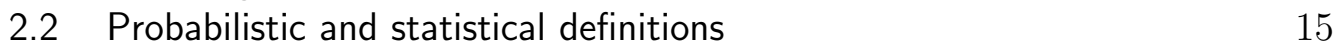

2.3 Propositional Dynamic Logic and Petri Nets 17

3 Propositional Dynamic Logic for Petri Nets (Petri-PDL) 25

3.1 Language and semantics 25

3.2 Axiomatic system 28

3.3 Soundness and completeness 28

3.4 Computational complexity 34

3.5 A Natural Deduction system for Petri-PDL 41

3.6 A Resolution system for Petri-PDL 49

3.7 Some examples $\quad 58$

3.8 Petri Nets modelling limitations $\quad 62$

4 Propositional Dynamic Logic for Stochastic Petri Nets 63

4.1 A stochastic approach for Petri Nets 63

4.2 A stochastic approach for Petri-PDL 66

$\begin{array}{lll}4.3 & \text { Axiomatic system } & 69\end{array}$

4.4 Soundness and completeness $\quad 69$

4.5 Computational complexity 75

4.6 A Natural Deduction system for $\mathcal{D S}_{3}$

4.7 Usage examples $\quad 76$

4.8 A note on the length of proofs $\quad 79$

5 Towards a transitive closure approach to $\mathcal{D S}_{3} \quad 80$

5.1 Basic definitions 80

5.2 Axiomatic system $\quad 82$

5.3 Soundness and completeness 83

$\begin{array}{ll}5.4 \text { Computational complexity } & 92\end{array}$

6 Conclusions and further work 93 


\section{List of Figures}

2.1 Example of a valid Petri Net 21

2.2 Petri Net for a simple elevator of five floors 21

2.3 Petri Net for a SMS send and receive 22

2.4 Basic Petri Nets 22

2.5 Example of application of Conflict rules 23

2.6 Examples of Sequence and Joint rules applications 23

2.7 Examples of the three cases of Repetition rule application 23

2.8 Example of Petri Net composition with its basic Petri Nets 24

3.1 Schema of a Petri Net for tiling game 36

3.2 A Petri Net where only $b$ has a token 58

3.3 A Petri Net for a chocolate vending machine 58

3.4 Petri Net for "Rock-Paper-Sicissors" game 59

3.5 Two markups of a Petri Net for a game where doors separate stages 60

3.6 A Petri Net for a game where the user open doors with keys 61

4.1 Stochastic Petri Net examples 66

4.2 Petri Net of a four agents system 76

4.3 A Kanban cell with failure 78 
Logic is not a body of doctrine, but a mirrorimage of the world. Logic is transcendental.

Ludwig Wittgenstein, Tractatus Logico-Philosophicus. 